\title{
Comparison of Microstructures on Elytral Disc of Some Species of the Genus Acmaeoderella Cobos, 1955 (Coleoptera: Buprestidae)
}

\author{
Üzeyir ÇAĞLAR \\ Vocational School of Health Services, Gazi University, Gölbaşı, Ankara, TURKEY \\ e-mail: ucaglar@gazi.edu.tr, ORCID ID: 0000-0002-8401-0155
}

\begin{abstract}
The external morphological characters of integumental scales in four species of Acmaeoderella Cobos, 1955 (Coleoptera: Buprestidae) were examined using stereo microscope (Olympus SZX-12) and scanning electron microscope (JEOL JSM 6060 SEM). Dried museum materials that are deposited in ZMGU (Zoology Museum of Gazi University) were used in this study. Specimens were examined under the stereo microscope (Olympus SZX-12). Similarities and differences among the species were discussed. Although the scales look alike under the stereo microscope, they showed a rather different pattern under SEM. The fine structure of scales was shown to be useful for species diagnostics.
\end{abstract}

Key words: Coleoptera, Buprestidae, Acmaeoderella, elytral microstructures, scales, SEM.

Çağlar, Ü., (2021). Comparison of microstructures on elytral disc of some species of the genus Acmaeoderella Cobos, 1955 (Coleoptera: Buprestidae). Journal of the Entomological Research Society, 23(1), 89-95. 


\section{INTRODUCTION}

The Buprestidae comprise about 14500 described species in 494 genera. (Volkovitsh 2001; Bellamy 2003). The genus Acmaeoderella Cobos, 1955 consists of six subgenera and more than 120 species in the Palaearctic region (Volkovitsh, Sakalian \& Georgiev 2015). The family is one of the most species-rich families in the order Coleoptera (Muskovits \& Hegyessy, 2002). The family Buprestidae is cosmopolitan and includes many species which are agricultural and forestry pests (Karagyan, Kuznetsova \& Lachowska 2004). Buprestidae are mainly wood-boring insects damaging weakened trees, though some species may attack healthy trees (Lodos \& Tezcan 1995). In addition, many buprestid species have received considerable interest from conservation biologists. Some species are red-listed in several countries, and buprestids are good indicators of biodiversity in the communities of saproxylic insects (Evans, Moraal \& Pajares 2007). Their development takes place in the bark of dead, foliaged trees or the ligneous stalk of perennial herbaceous plants (Muskovits \& Hegyessy, 2002).

Buprestidae are commonly known as jewel beetles (Muskovits \& Hegyessy, 2002; Evans, Moraal \& Pajares 2007).The external morphology of jewel beetles are often used in keys. In general, jewel beetles are heavily sclerotized beetles (Muskovits \& Hegyessy, 2002). Abdomen of the most species is completely covered by the elytra which have longitudinal grooves, or rows of punctures, or longitudinal keels (Evans, Moraal \& Pajares 2007). Scutellum is reduced.in Acmaeoderella and the species of this genus are mostly small cylindrical beetles covered with scale-like hairs or wide scales (Muskovits \& Hegyessy, 2002).

Character searching is one of the main tasks for taxonomists and is always time-consuming; finding out new sets of diagnostic characters is especially important (Liu, Schönitzer \& Yang, 2009). In this article, we present a detailed examination of the elytral surface structures and scales of some species of the Acmaeoderella genus using both stereo microscope and scanning electron microscope (SEM). Diagnostic value of scales for species identification can be best illustrated by utilizing the SEM.

\section{MATERIAL AND METHODS}

Four species of Acmaeoderella Cobos, 1955 were used in this study, which are Acmaeoderella (Liogastria) chrysanthemi (Chevrolat, 1854), A. (Omphalothorax) despecta (Baudi di Selve, 1870), A. (O.) longissima (Abeille de Perrin, 1904) and A. (Carininota) mimonti (Boieldieu, 1865). Specimens were studied from the various habitats and altitudes of the Asian part of Turkey collected by sweeping net between 2013 and 2014. All specimens are deposited in the Zoological Museum of Gazi University (ZMGU).

Dried museum samples were examined under stereo microscope (Olympus SZX-12). For examination under Scanning Electron Microscope, samples were cleaned, dried and mounted with double-sided carbon tape on SEM stubs, coated with gold in a Polaron SC 502 Sputter Coater, and examined with a JOEL JSM 6060 
Comparison of Microstructures on Elytral Disc

SEM operated at $10 \mathrm{kV}$. We paid special attention to the middle part of the elytral disc in all species and then investigated the external morphology of scales under the different magnifications.

\section{RESULTS}

\section{Stereomicroscopic examination}

The species (Acmaeoderella chrysanthemi, A. despecta, A. longissima and A. mimonti) were first investigated under a stereo microscope (Figs.1a-d). All species have irregular yellow-colored patterns on the elytra. While these patterns on the elytra are longitudinal in $A$. crhysanthemi, these patterns in the other three species $(A$. despecta, $A$. longissima, $A$. mimonti) are in the form of irregular transverse bands or spots (Figs.1a-d). In addition, it is seen that the scales on the elytra look similar in all species, but these scales are sparser in $A$. mimonti (Fig.1d) and more dense in other species (A. chrysanthemi, $A$. despecta and A. longissima) (Figs.1a-c).
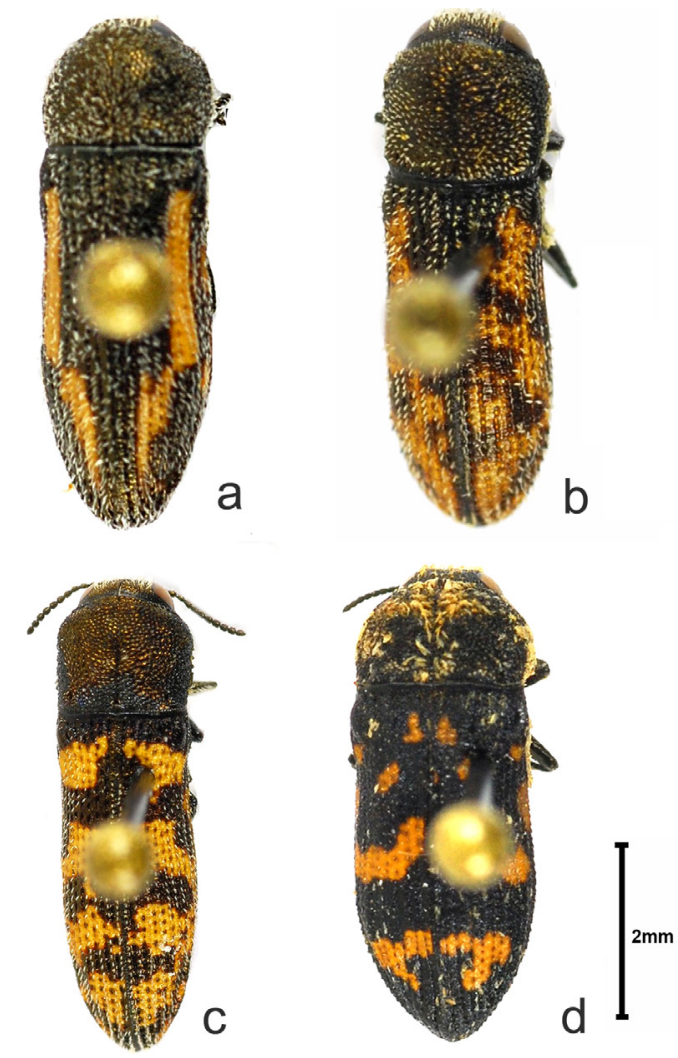

Fig. 1. Dorsal view of the Acmaeoderella species under a stereomicroscope; a) A. chrysanthemi (Chevrolat, 1854), b) A. despecta (Baudi di Selve, 1870), c) A. Iongissima (Abeille de Perrin, 1904), d) A. mimonti (Boieldieu, 1865). 


\section{SEM examination}

The whole body, elytra surface and scales of all species were examined in detail under the scanning electron microscope. In A. chrysanthemi, A. despecta, A. longissima the body is cylindrical (Figs. 2a-C), in A. mimonti, the body is flattened dorso-ventrally (Fig. 2d).

We paid particular attention at the middle part of the elytral disc in all species. In A. chrysanthemi there are deep but not adjacent longitudinal strial punctures on the elytra.

Scales arise from piliferous micropunctures which in turn located on the bottom of larger punctures which are well visible on the photos. Usually iterstriae are alternatively wider and narrower; normally narrower interstriae bear uniseriate (1 row) scales, while wider ones - multiseriate (2,3> rows) scales (Fig. 3a). In A. despecta, there are deep and sometimes adjacent punctures in the elytral striae. In the interstriae, the scales are arranged in a single row (Fig. 3b). In A. longissima, there are very deep adjacent strial punctures in the elytral striae. In the elevated area between these strial punctures, scales are arranged in a single row (Fig. 3c). In A. mimonti, there are shallow, narrow and longitudinally elongated strial punctures on the elytra. There are nearly oval scales and short setae in the interstriae (Fig. 3d).

The scales on the elytra were observed to they have different leaf shapes performed by scanning electron microscope. In A. chrysanthemi, the scales are lanceolate, the edges are serrate and they have a rib in the middle (Fig. 4a). In A. despecta, the scales are lanceolate, the surface with 2-3 ribs (Fig. 4b). In A. longissima, the scales are spatulated, the edges are serrate and the surface with 3-5 ribs (Fig. 4c). In A. mimonti, the scales are elliptical, and a saw-shaped rib extends in the middle. The edges of the scales are saw-like and the surface is covered with numerous spines (Fig.4d).
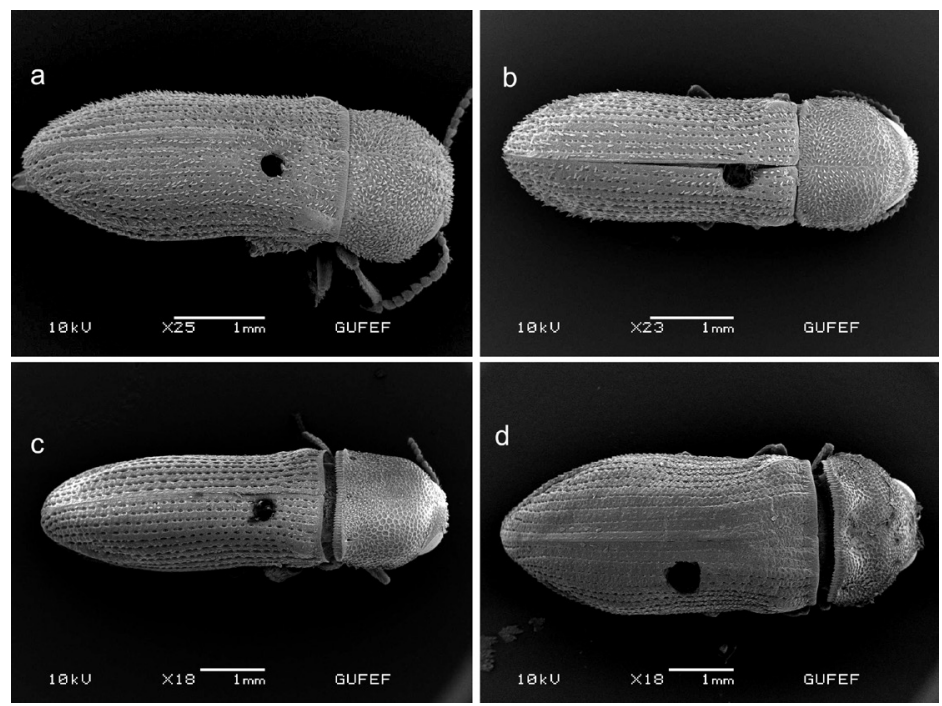

Fig. 2. Generel SEM photos of dorsal view of the Acmaeoderella species; a) A. chrysanthemi (Chevrolat, 1854), b) A. despecta (Baudi di Selve, 1870), c) A. Iongissima (Abeille de Perrin, 1904), d) A. mimonti (Boieldieu, 1865). 
Comparison of Microstructures on Elytral Disc
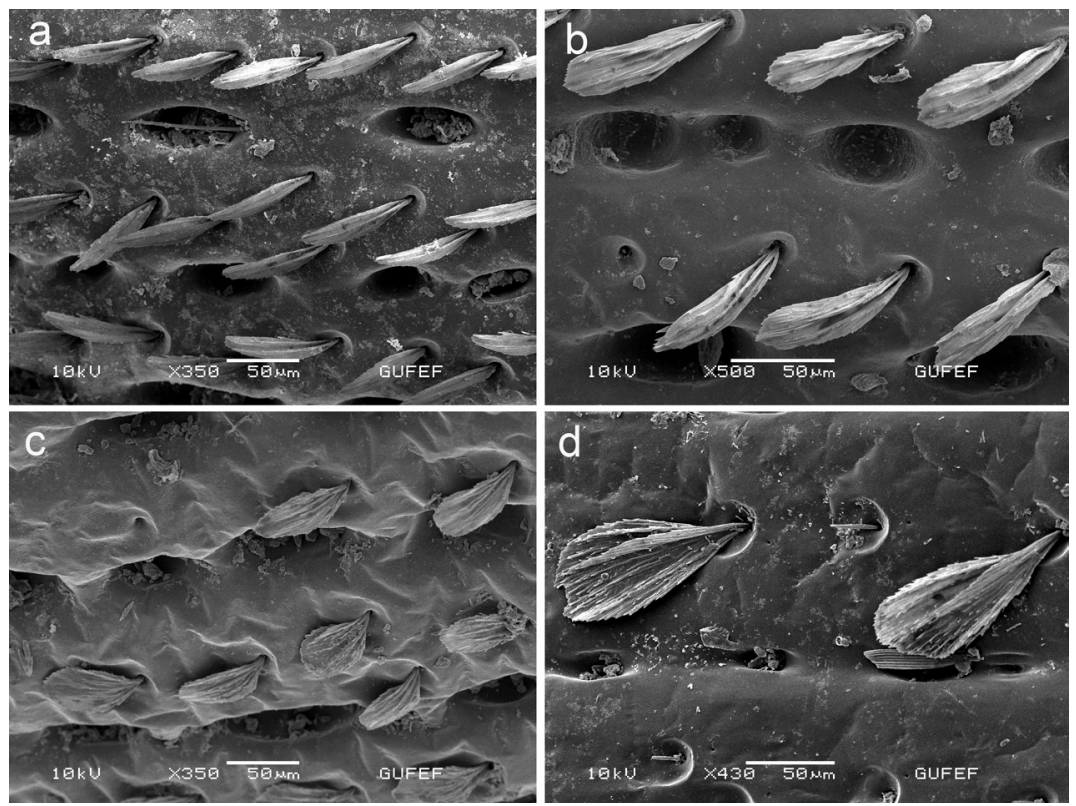

Fig. 3. Generel SEM photos of dorsal view of the Acmaeoderella species; a) A. chrysanthemi (Chevrolat, 1854), b) A. despecta (Baudi di Selve, 1870), c) A. Iongissima (Abeille de Perrin, 1904), d) A. mimonti (Boieldieu, 1865).
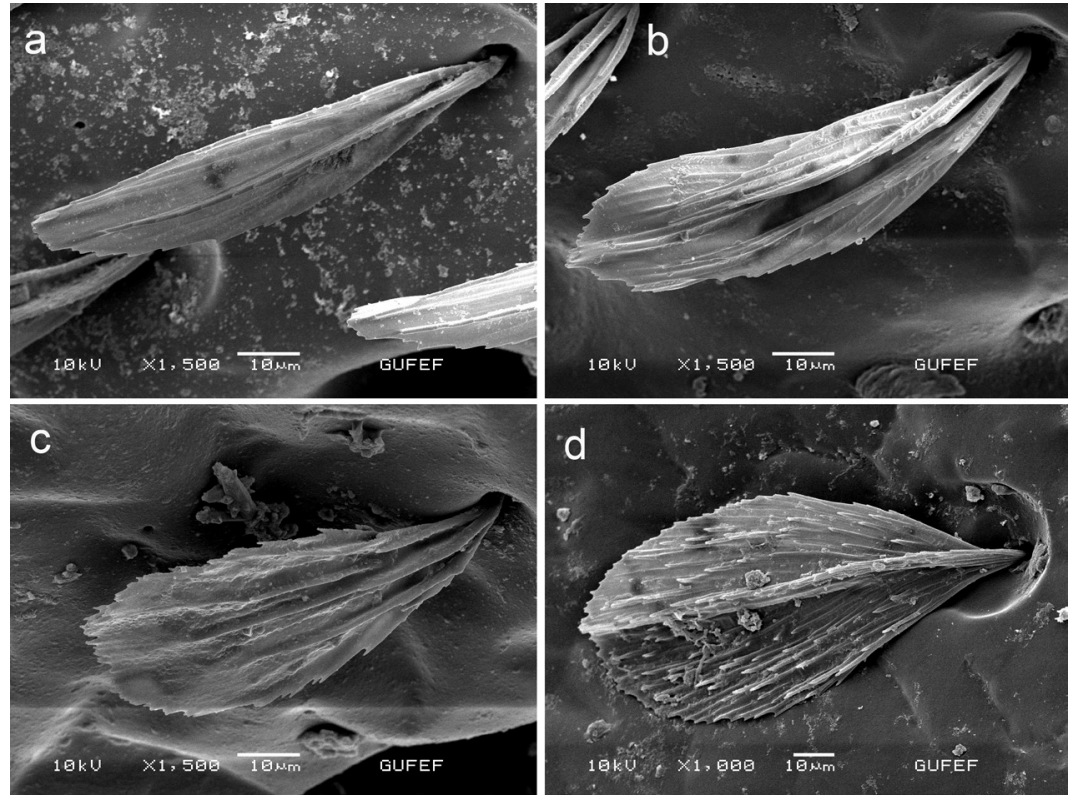

Fig. 4. SEM photos of scales of the Acmaeoderella species; a) A. chrysanthemi (Chevrolat, 1854), b) $A$. despecta (Baudi di Selve, 1870), c) A. longissima (Abeille de Perrin, 1904), d) A. mimonti (Boieldieu, 1865). 
ÇAĞLAR, Ü.

\section{DISCUSSION}

In this study the scales of four species of the genus Acmaeoderella (Coleoptera: Buprestidae) were investigated under a scanning electron microscope for the first time. The similarities and differences of some special microstructure characters among species were discussed.

Some morphological characters in taxonomy are very important such as hairs, setae, punctures, color and are used in diagnoses (Bílý, Kubáň, Volkovitsh \& Kalashian, 2011; Booth, Cox, \& Madge, 1990; Erbey \& Candan, 2013, 2015; Hoffmann, 1954, Jendek, 2001; Manley, 1987; Sun \& Bhushan, 2012; Volkovitsh,1979, 1983; Volkovitsh \& Bílý 1979; Wagner, Neinhuis \& Barthlott, 1996). Elytral colors are ecologically very important, and elytral microstructure is also very important as a model in technology and engineering. The structural colors of elytra are actually interference colors mixing partly to produce camouflage by matching the color of the environment. The study of the structure, functional and mechanical properties of beetle elytra gives an opportunity to understand their behavior and characteristics. This can form a good basis for the research and development of bioinspired materials, structures, and smart devices. (Sun \& Bhushan, 2012).

While the colors of the elytra differ in the examinations under the stereo microscope, the scales look similar (Figs.1a-d). Under the scanning electron microscope, there is a difference in the general body shapes in low magnification examinations, while there is no significant difference in the structures on the elytra (Figs.2a-d). In addition, microstructures (scales and punctures) on the elytra in high magnification examinations under scanning electron microscopy are different in all species and have their own characteristics (Figs.3a-d, Figs.4a-d).

As a result, microstructures on the elytra surface can be used as taxonomic characters in species identification. To give more effective results, it was concluded that the populations of samples collected from different localities for each species should be compared. In addition, the investigation of the surface morphology of scales in insects may help in differentiation of similar species that have similar shape and color. Finally, when further investigated, elytral structures in beetles can help develop new bio-inspired designs in the fields of material science and technology.

\section{REFERENCES}

Bellamy, C.L. (2003). An illustrated summary of the higher classification of the superfamily Buprestoidea (Coleoptera). Folia Heyrovskyana, Supplement, 10, 1-197.

Bílý, S., Kubáń, V., Volkovitsh, M.G., \& Kalashian, M.Yu. (2011). Order Coleoptera, family Buprestidae. Arthropod Fauna of the UAE, 4:168-223.

Booth, R.G., Cox, M.L., \& Madge, R.B. (1990). Lie Guides to insects of importance to man, 3. Coleoptera. Printed in the UK at the University Pres, Cambridge, 384pp.

Erbey, M. \& Candan, S. (2013). Fine structure of the scales of Tychius Germar, 1817 (Coleoptera: Curculioninae) species. Acta Zoologica Bulgarica, 63(3), 413-416.

Erbey M. \& Candan S. (2015). Comparative morphology of scales in Cionus Clairville, 1798 (Coleoptera: Curculionidae) species. Journal of Entomology and Zoology Studies, 3(1), 246-249. 
Comparison of Microstructures on Elytral Disc

Evans, H.F., Moraal, L.G, \& Pajeres, J.A. (2007). Biology, ecology and economic importance of Buprestidae and Cerambycidae. In: Lieutier F., Day, K.R., Battisti, A., Gregoire, J.C., Evans HF (Eds.) Bark and wood boring insects in living trees in Europe, a synthesis. Springer, Dordrecht, 447-474.

Hoffmann, A. (1954). Faune de France, Coleopteres, Curculionides, deuxime partie 59, Paris, 487-1208.

Jendek, K. (2001). A Comparative study of the abdomen in the family Bupretidae (Coleoptera), Acta Musei, Moraviae, Scientiae Biologicae, 86,1-41.

Karagyan, G., Kuznetsova, V.G., \& Lachowska, D. (2004). New Cytogenetic Data on Armenian Buprestids (Coleoptera, Buprestidae) with a Discussion of Karyotype Variation within the Family. Folia Biologica (Kraków), 52(3-4), 151-158.

Liu, L.Y., Schonitzer, K., \& Yang, J.T. (2009). Microstructural characters as a tool for taxonomy. (Coleoptera: Bostrichidae: Minthea and Dinoderus). Nachrichtenblatt der Bayerischen Entomologen. $58(3 / 4), 57-61$.

Lodos, N. \& Tezcan, S. (1995). Türkiye entomolojisi V Buprestidae (Genel uygulamalı ve faunistik). Entomoloji Derneği Yayınları No: 8. Ege Üniversitesi Basımevi, İzmir.

Manley, G.V. (1987). Four new Acmaeodera (Coleoptera: Buprestidae) from Honduras, with Notes on Species from Central America, The Coleopterist Bulletin, 41(1), 15-26.

Sun, J. \& Bhushan, B. (2012). Structure and mechanical properties of beetle wings: a review, The Royal Society of Chemistry, (2): 12606-12623.

Muskovits, J. \& Hegyessy, G. (2002). Magyarország díszbogarai. Jewel beetles of Hungary (Coleoptera: Buprestidae). Grafon Kıado Nagykovacsı, 1-404.

Volkovitsh, M.G. (1979). A Review of Palearctic groups of the Tribe Acmaeoderini (Coleoptera, Buprestidae), Entological Review, 58(2), 78-99.

Volkovitsh, M.G. (1983). New Buprestids of the Tribe Acmaeoderini (Coleoptera, Buprestidae) from the Palaearctic and South-Eastern Asia, Entological Review, 62(3),103-117.

Volkovitsh, M.G. (2001). The comparative morphology of antennal structures in Buprestidae (Coleoptera): evolutionary trends, taxonomic and phylogenetic implications. Part 1. Acta Musei Moraviae Scientiae biologicae (Brno) 86, 43-169.

Volkovitsh, M.G. \& Bily, S. (1979). New species of Acmaeoderini from South-West Asia (Coleoptera, Bupresidae). Acta Entomologica Bohemoslovaca, 76, 330-336.

Volkovitsh, M.G., Sakalian, V., \& Georgiev, G. (2015). A checklist and a key to the taxa of the subfamily Polycestinae Lacordaire, 1857 (Coleoptera: Buprestidae) in Bulgaria. Acta Zoologica Bulgarica. 67(4), 471-478.

Wagner, T., Neinhuis, C., \& Barthlott, W. (1996). Wettability and Contaminability of insect wings as a function of their surface sculptures. Acta Zoologica (Stockholm), 77(3), 213-225. 